\title{
Fischer, Brodwyn A Poverty of Rights: Citizenship and Inequality in Twentieth-Century Rio de Janeiro
}

Samuel Silva Rodrigues de Oliveira*

Stanford, California: Stanford University Press, 2008. 488p.

A Poverty of Rights: Citizenship and Inequality in Twentieth-Century Rio de Janeiro is the result of Brodwyn Fischer's 1999 Harvard dissertation. In it she analyzes the process of rights formation in the organization of the Brazilian state and society and the conflicts of class, race, and gender which permeate the constitution of the urban space in Rio de Janeiro.

Taking as the core of its analysis the structured shocks in the daily life of the poor in Rio de Janeiro, A Poverty of Rights is an original contribution to the social history of urban poverty. The work draws on the renewal of the history of recent time, highlighting the question of favelas. As Knaus and Brum note,

while urban history and the history of Rio de Janeiro city in particular became consolidated as a field of institutionalized research of historians from the 1980s onwards, it would only be in the first decade of the twenty-first century that production in postgraduate history programs began to emerge in which the favela appears as an object of historical studies. (Brum, 2012, p.121)

Along with the books Um século de Favela (2001), organized by Alba Zaluar and Marcos Alvito, Favelas Cariocas (2005), by Maria Lais Pereira da Silva, A invenção da favela (2005), by Lícia do Prado Valladares, and Favelas cariocas: ontem e hoje (2012), organized by Marco Antônio da Silva Mello, Luiz Antônio Machado da Silva, Letícia de Luna Freire and Soraya Silveira Simões, Fischer's work is part of the renewal of historical studies of the city of Rio de Janeiro, taking as a focus the problematization of representations and practices of poverty and the urban space.

*Doctoral Candidate, Programa de Pós-Graduação em História, Política e Bens Culturais, Centro de Pesquisa e Documentação de História Contemporânea do Brasil (CPDOC-FGV). Faperj Grantee. samu_oliveira@yahoo.com.br 
The differential in Fischer's research is her temporal focus, the scope of the sources used and the way in which the question of citizenship is focused on. Tackling a question with a wide-ranging tradition in History and the Social Sciences related to Brazil and Latin America - the relationship between inequality, rights and the urban space -, Fischer develops an argument centered on processes which occurred between the 1920s and the beginning of the 1960s. This was a period of rapid urbanization, industrialization, and the expansion of the suburbs, favelas and other urban forms. The temporal focus is also justified by the structure of power which presided over the Carioca political sphere. From the first Republican Constitution (1891) until 1960, Rio de Janeiro had a mayor appointed by the president and approved by the Senate. Councilors were elected for the municipal legislature, and deputies and senators for the federal legislature. As it was the capital of the republic, reforms in the political system found widespread repercussion and expression in the political and cultural life of the city. Moreover, the Lacerda administration (19611965) was a landmark for studies of urban poverty in Rio de Janeiro: the commencement of a removal policy which culminated in the partial or complete eviction of fifty to sixty favelas (affecting around 100,000 people) profoundly altered the routine and shaping of the Carioca urban scene.

In addition to the temporal focus, the author uses various types of documents to develop her argument. Since the subordinate classes did not leave organized archives about their practices, she justifies the use of sambas, newspapers, photographs, political speeches, reports from public agencies, bills, legislations, letters, and legal cases, among other documents, to understand the strategies of the poor in the conquest of citizenship. The material accumulated by the author is eclectic, dispersed in a myriad of places and institutions, and establishes various cultural filters to represent urban poverty. By reading a kaleidoscopic of records, added to the analysis of the specific bibliography about the relationship between law and citizenship, she manages to raise relevant problems in the analysis of the sociability and practices of subordinate groups.

To analyze the heterogeneous documentary corpus accumulated, the analysis is organized in four parts which have a certain autonomy, and each of which consists of two chapters. In the first part, entitled "Rights in the Cidade Maravilhosa," she analyzes the process of the formation of urban space in Rio de Janeiro and the classification of the poor population's forms of habitation. She is interested in emphasizing how the construction of the illegality of forms of habitation and living in the city, the restriction of the political space 
dominated by the interference of the federal government, and the legislative restrictions on the growth of favelas, contributed to the reproduction of a clientelist incorporation of the poor in urban politics. In the second part, entitled, “Labor, Law, and Social Justice in Vargas' Rio," Fischer uses letters sent to President Getúlio Vargas as the principal material of analysis. The enactment of labor legislation, Vargas' discourse incorporating the worker in the national political community, and the strategies of popular groups to win social rights are the axis of his analysis. In the third part, entitled "Law of the poor in the Criminal Court", she analyzes how crime was defined by criteria of the judicial system and popular morality, and how this came of forces was altered by the reform of the Penal Code in the 1940s with the emergence of the idea of 'previous life.' In the final part, entitled "Owners of the Illegal City," Fischer analyzes conflicts over land and the right to habitation in the rural zone and in the favelas of Rio de Janeiro.

The Vargas Era (1930-1945) was a period of great transformations in regards to the rights of the working class. This political and social fact has already been analyzed by different authors, and has become a classical theme in Brazilian historiography. Fischer manages to bring a novelty to this question, as she does not restrict the analysis to social and political rights, but looks at how the penal and urban reforms of Rio de Janeiro also affected the citizenship of popular groups. Mass politics and the 1932 Electoral Code, the right to the city and the 1937 Works Code of Rio de Janeiro, civil law and the 1940 Penal Code, and social rights and the Consolidation of Labor Laws (1943) are the concerns of her analysis, as is shown in the division of the parts of the book.

The author shows that the winning of rights for the 'poor,' for informal workers, and a significant part of the Brazilian population without civil registration, resulted in situations of great ambiguity. Far from developing a linear narrative of the evolution of the state and society in the sedimentation of rights, as in the classic analysis of T. H. Marshall in Citizenship, social class and status, or incorporating the discourse of the political ideologies which transformed Vargas into a myth, the author present the contingency of the situations experienced by the 'poor.' She is concerned with the way people with little formal education and little economic and political power constructed various strategies to fight for rights, something always marked by contingency in their lives and social experiences.

By stressing the process of the formation of rights and citizenship, Fischer emphasizes that the poor "formed the numerical majority in various Brazilian cities, and that they shared experiences of few conquests, political exclusion, 
social discrimination, and residential segregation," shaping "an identity and in some moments a common agenda" (Fischer, 2008, p.4). She understands that his group has not been researched in a verticalized manner, since the social history of the period between the 1930s has privileged the analysis of the working class conscience, of afro-descendants, foreign immigrants, and women. According to the author,

the truth is that in Rio - as in many place, from Mexico City to Caracas, to Lima or Salvador - neither race, nor gender, nor working class were generalized or powerful enough identities to define the relationship between the poor urban population and its surrounding society during most of the twentieth century. Very few people actually belonged to the organized working class; many racial and regional identities competed with each other in many spheres; many cultural, economic, and personal ties linked the poorest to clients, employers, and protectors from other social categories; while in addition many migrants went to the city to feed their hopes. The poor people in Rio understood themselves, in part as women and men, in part as white and black, natives or foreigners, working class or not. However, they also understood themselves as a specific segment, simply as poor people trying to survive in the city. (Fischer, 2008, p.3)

Fischer also stresses that the experience of urban poverty cannot be reduced to the definition of the working class in the class Marxist sense. Reducing the experience of urban poverty to a class situation incurs the risk of losing the ethnic, racial, and gender dimensions which mold the identities and relations woven with various socio-political authorities. Social inequality is seen in the book as a condition involved in various types of situations and which transversally cuts across the relations woven in Brazilian state and society.

For this reason A Poverty of Rights is an important work for renewing studies about citizenship in the period before the 1930s and the social history of urban poverty in Rio de Janeiro.

\section{REFERENCES}

ALVITO, M.; ZALUAR, A. (Org.) Um século de favela. Rio de Janeiro: Ed. FGV, 2001. BRUM, Mario Sergio Ignácio. Cidade Alta: história, memórias e estigma de favela num conjunto habitacional do Rio de Janeiro. (Prefácio de Paulo Knauss). Rio de Janeiro: Ponteio, 2012.

MARSHALL, T. H. Cidadania, classe social e status. Rio de Janeiro: Zahar, 1967. 
MELLO, M. A. da Silva; MACHADO DA SILVA, L. A., FREIRE, L. L.; SIMÕES, S. S. (Org.) Favelas cariocas: ontem e hoje. Rio de Janeiro: Garamond, 2012.

SILVA, Maria Lais Pereira da. Favelas cariocas (1930-1964). Rio de Janeiro: Contratempo, 2005.

VALLADARES, Lícia do Prado. A invenção da favela: do mito de origem à favela.com. Rio de Janeiro: Ed. FGV, 2005. 